\title{
Properties of Fibrous Scaffolds from Poly(3-Hydroxybutyrate), Polylactide, Polyglycolide and Poly(Lactide-Glycolide) with Various Methods of Electrostatic Forming
}

\author{
Dmitry B. Goncharov and Alexey G. Sukovatyi* \\ Institute of Biophysics SB RAS \\ 50/50 Akademgorodok, Krasnoyarsk, 660036, Russia
}

\begin{abstract}
Received 03.06.2015, received in revised form 04.06.2015, accepted 25.04.2016
Fibrous scaffolds from polymer solutions of poly-3-hydroxybutyrate, polylactide and polyglycolide, and copolymer of poly(lactide-glycolide) were obtained using electrostatic shaping with one or two feeding capillaries on one collecting manifold and their characteristics were studied. The spatial distribution of fibers having different chemical structure in layers of fibrous scaffolds occurred when two feeding capillaries were used. The composition of polymer solutions influenced on the hydrophilichydrophobic properties of fibrous scaffolds, regardless of the method of electrostatic molding.
\end{abstract}

Keywords: fibrous scaffolds, electrostatic formation, physical-chemical and mechanical properties.

DOI: $10.17516 / 1997-1389-2016-9-2-212-222$.

(c) Siberian Federal University. All rights reserved

* Corresponding author E-mail address: a.sukovatiy@ya.ru 


\title{
Свойства нетканых изделий
}

\author{
из поли-3-гидрокисбутирата, полилактида, \\ полигликолида и поли(лактид-гликолида) \\ при различных способах
}

электростатического формования

\author{
Д.Б. Гончаров, А.Г. Суковатый \\ Институт биофизики СО РАН
}

Россия, 660036, Красноярск, Академгородок, 50/50

\begin{abstract}
Методом электростатического формования с использованием одного или двух подаюших капилляров на один собирающий коллектор получены нетканые изделия из растворов полимеров поли-3-гидроксибутирата, полилактида $u$ полигликолида $u$ сополимера поли(лактид-гликолида) и исследованы их характеристики. Показано, что при использовании двух подающих капилляров происходит пространственное распределение волокон, имеющих различную химическую структуру, по слоям нетканого изделия. Выявлено влияние состава используемых растворов полимеров на гидрофильно-гидрофобные свойства нетканых изделий вне зависимости от способа электростатического формования.
\end{abstract}

Ключевые слова: нетканые изделия, электростатическое формование, физико-химические и механические свойства.

\section{Введение}

Электростатическое формование (электроспининг) является современным способом получения нетканых изделий на основе ультратонких волокон. К его достоинствам можно отнести относительную простоту, низкую стоимость, высокую скорость производства, широкий выбор используемых материалов и универсальность. Кроме того, данный метод позволяет контролировать диаметр получаемых волокон и микроструктуру нетканых изделий, на их основе.

Изделия, изготовленные методом электростатического формования, обладают высокой пористостью с размерами пор в несколько десятков раз больше диаметров самих волокон. Пористость обеспечивает высокую про- ницаемость для жидкостей и биологических агентов, а огромная доступная площадь поверхности позволяет регулировать ее функциональность (Huang et al., 2003; Pham et al., 2006; Teo, Ramakrishna, 2006; Zhang, Yu, 2014).

В последние годы для производства нетканых изделий методом электростатического формования все чаще используют биоразлагаемые полимеры, что значительно расширяет область их применения (Kriegel et al., 2008; Schiffman, Schauer, 2008; Hosseini Ravandi et al., 2014; Buschle-Diller et al., 2006). К числу таких полимеров относятся полигидроксиалканоаты с различной химической структурой и физико-химическими свойствами. Наиболее распространённым 
и широко используемым образцом данного класса является полимер 3-гидроксимасляной кислоты (ПЗГБ) (Волова и др., 2013; Гончаров и др., 2012). Однако в силу высокой кристалличности ПЗГБ (70 \%) нетканые изделия из этого полимера имеют некоторые ограничения в использовании (Николаева и др., 2011; Philip et al., 2007).

Чаще всего процесс улучшения характеристик нетканых изделий ориентирован на использование для их получения смесей различных полимеров, что позволяет влиять на их морфологию, физико-химические и физико-механические свойства, улучшая их качество в целом (Volova et al., 2014). Возможность объединения различных полимеров в процессе формования позволяет создавать нетканые материалы с широким диапазоном их применения (Sahay et al., 2012; Katarzyna, Gouma, 2006; Khalil et al., 2013). Еще один подход для улучшения качества нетканых изделий заключается в использовании различных способов собственно процесса электростатического формования. Самым универсальным способом является формирование нетканых изделий с применением одного подающего капилляра и, соответственно, одного полимерного раствора, который может включать в себя два и более типа полимеров. В этом случае составляющие полимерного раствора равномерно распределены в структуре волокон нетканого изделия (Kancheva et al., 2015). Второй способ основан на использовании двух и более подающих капилляров на один собирающий коллектор, что позволяет изготавливать мембраны с волокнами из разных полимеров, распределенных в пространственной структуре мембраны. Оба способа позволяют модифицировать свойства нетканого материала, к которым можно отнести физико-механические характеристики, свойства поверхности.
В настоящей работе впервые поставлена задача получения и сравнительного изучения свойств нетканых изделий, полученных из поли-3-гидрокисбутирата, полилактида, полигликолида, поли(лактид-гликолида) и их смесей при различных способах электростатического формования.

\section{Материалы и методы}

Изготовление нетканых изделий

Для изготовления нетканых изделий из ультратонких волокон использовали полимерные растворы гомополимера поли3-гидроксибутирата (ПЗГБ), полилактида (ПЛА), полигликолида (ПГ) и сополимера поли(лактид-гликолида) (ПЛГ) с равным содержанием компонентов. ПЗГБ синтезирован в лаборатории хемоавтотрофного биосинтеза Института биофизики СО РАН (Россия). ПЛА и ПГ были произведены фирмой Sigma Aldrich Co. (Германия), поли(лактид-гликолид) - фирмой Acros Organics (США).

Для получения растворов полимеров использовали хлороформ («Химреактивснаб», Россия) для полимерного раствора ПЗГБ с полилактидом и гексафлюороизопропанол (hexafluoroisopropanol, HFIP) (Sigma-Aldrich Co., Германия) для растворов ПЗГБ с полигликолидом и ПЗГБ с сополимером поли(лактидгликолидом).

Нетканые изделия были изготовлены на автоматической установке электростатического формования Nanon 01A (MECC Inc., Япония). Для каждого типа полимера применяли растворы с концентрациями 8 мас.\%. Раствор помещался в пластиковый капилляр (внутренний диаметр 13 мм), который фиксировали в горизонтальном шприцевом насосе. Скорость подачи раствора составляла 5 мл/ч, величина приложенного напряжения 30 кВ, рабочее расстояние составляло 15 см. В каче- 


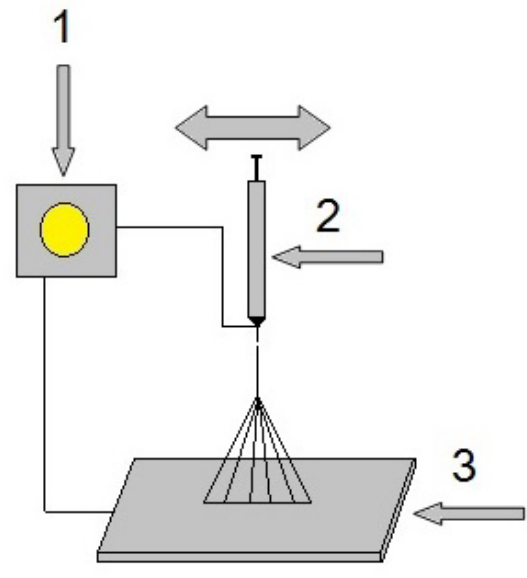

$\boldsymbol{a}$

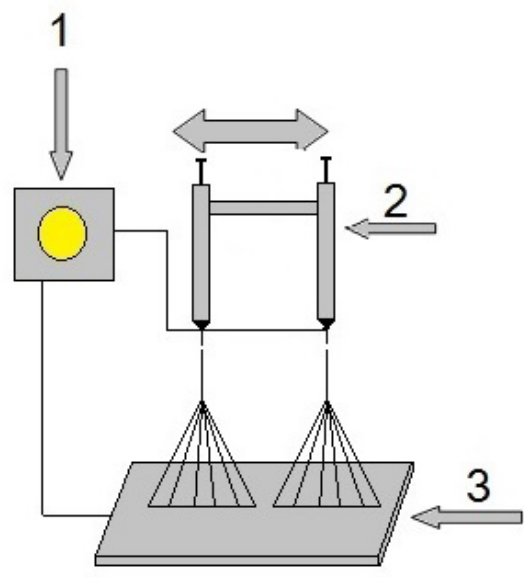

6

Рис. 1. Схема процесса электростатического формования с использованием: $a$ - одного подающего капилляра; $\sigma$ - двух подающих капилляров (из двух разных полимерных растворов одновременно) на один собирающий коллектор (1 - источник высокого напряжения; 2 - шприцевой насос; 3 - собирающий коллектор)

стве коллектора использовали стальную пластину, покрытую фольгой для лучшего сбора материала.

Схема процесса электростатического формования с одним подающим капилляром представлена на рис. 1а; двух подающих капилляров (для двух разных полимерных растворов одновременно) на один собирающий коллектор - на рис. 16.

Параметры процесса формования были подобраны так, чтобы толщина нетканого изделия была постоянна вне зависимости от состава раствора и метода формирования образца.

\section{Исследование свойсть}

нетканых изделий

Микроструктуру поверхности и диаметр ультратонких волокон нетканого изделия анализировали при помощи сканирующего электронного микроскопа ТM-3000 (Hitachi HT Corporation, Япония). Предварительно образцы покрывали напылением золотом. Диаметр волокон измеряли на основе ана- лиза SEM-изображений с использованием программы ImageJ. Для каждой микрофотографии измерены диаметры не менее чем 50 отдельных ультратонких волокон.

Физико-механические свойства нетканых изделий были исследованы с помощью электромеханической разрывной машины Instron 5565 (Великобритания). Исследуемые образцы нетканых изделий подготавливали в форме гантели длиной 50 мм, шириной 6,1 мм и толщиной 100 мкм. Толщину образцов измеряли, используя электронный цифровой микрометр LEGIONER EDM-250.001 (Legioner, Китай). Измерения проводили при комнатной температуре. Модуль Юнга (Е, МПа), напряжение при разрыве $(\sigma$, МПа) и удлинение при разрыве $(\varepsilon, \%)$ были рассчитаны с помощью программного обеспечения Bluehill 2 (Elancourt, Франция). Погрешность измерения не превышала $10 \%$.

Краевые углы смачивания поверхности изделий измеряли с использованием программного обеспечения DSA-4 на приборе 
DSA-25E (Krüss, Германия). На поверхность образца наносили капли воды объемом 1,5 мкл и в полуавтоматическом режиме Circle измеряли краевые углы смачивания не менее чем в пяти различных областях образца.

Статистический анализ результатов проводили с использованием стандартного программного пакета Microsoft Excel. Были найдены средние арифметические и стандартные отклонения. Статистическую значимость результатов определяли с помощью критерия Стьюдента (уровень значимости $\mathrm{P} \leq 0,05)$.

ПЗГБ

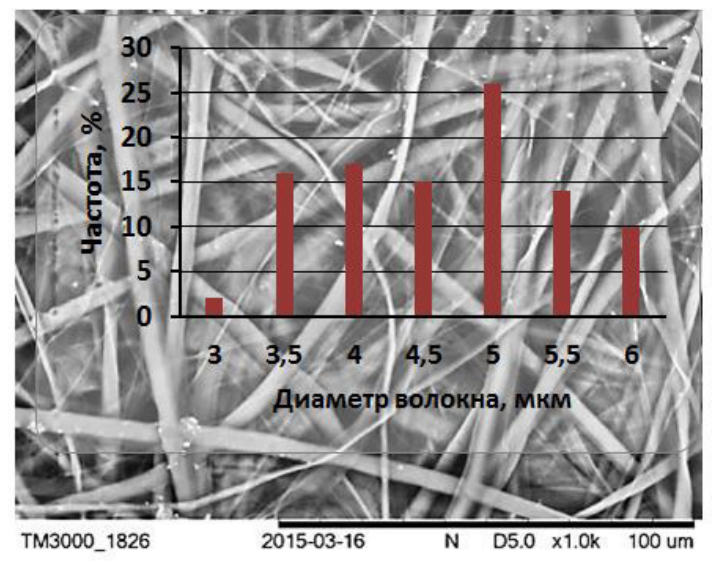

ПЛА

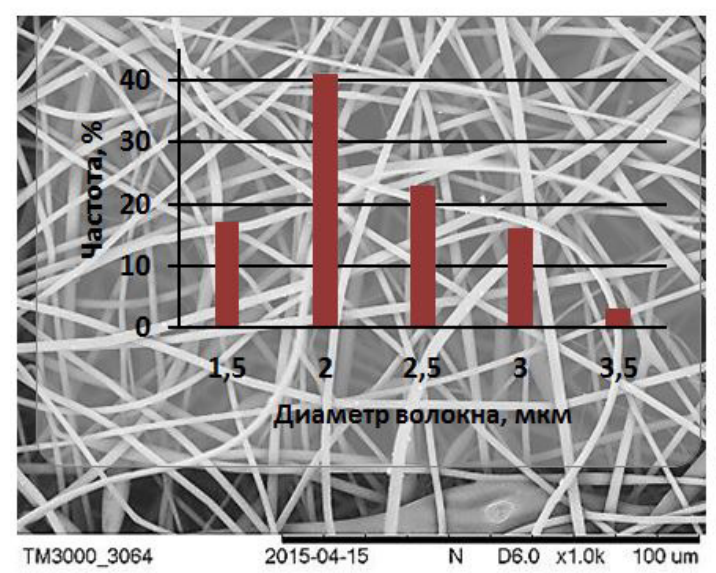

\section{Результаты и обсуждение}

Влияние химического состава полимеров

на морфологию нетканых изделий

Первоначально из каждого типа полимера были сформированы нетканые изделия и охарактеризованы их морфология, структура волокон и распределение по величине диаметра.

Для всех типов полимеров были получены ультратонкие волокна с равномерной, гладкой структурой поверхности без видимых дефектов в виде бус (рис. 2). Анализ результатов измерений диаметра волокон для
III

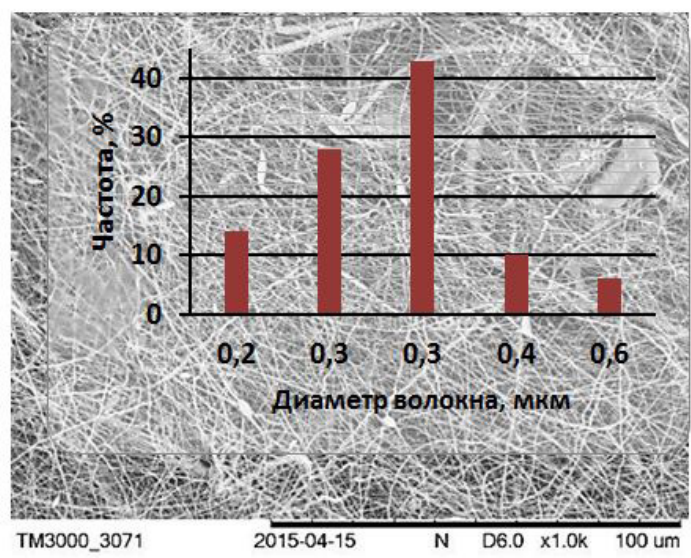

ПЛГ

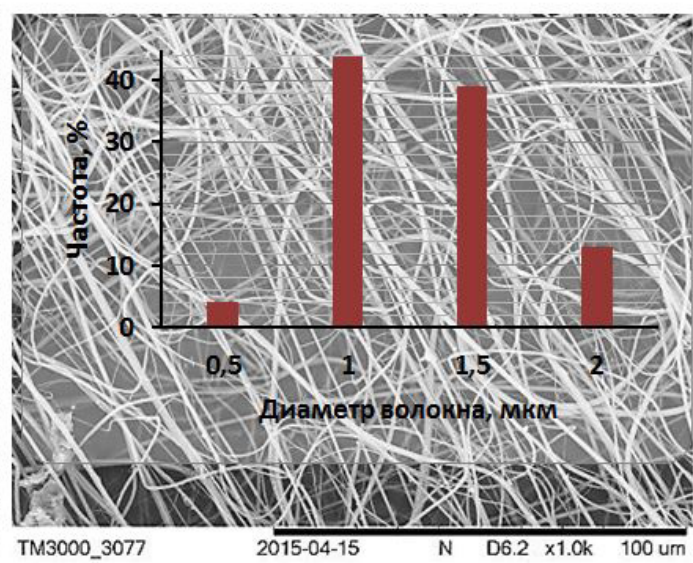

Рис. 2. РЭМ-изображения и распределение диаметра волокон нетканых изделий, образованных из поли3-гидроксибутирата, полилактида, полигликолида и сополимера поли(лактид-гликолида) 
различных типов полимеров показал явную зависимость этого параметра от типа полимера при одинаковых параметрах процесса электростатического формования. Самые высокие значения диаметра волокон были получены для ПЗГБ, где максимальное значение составляло 6,0 мкм, а средний диаметр 4,5 мкм. Самые низкие величины диаметра волокон были зафиксированы у образцов нетканых изделий из чистого полигликолида, у которых максимальный диаметр волокон не превышал 0,6 мкм, а среднее значение составляло 0,3 мкм.

Волокна из ПЛА имели максимальный диаметр 3,5 мкм, а средний диаметр составлял 1,5 мкм. Из сополимера ПЛГ - 2,0 мкм и 1,0 мкм соответственно.

Сравнивая полученные результаты для исследуемых полимеров, необходимо отметить значительное превышение диапазона величины диаметра волокон для ПЗГБ над аналогичным параметром полимеров ПЛА, ПГ и сополимера ПЛГ.

\section{Влияние способа}

электростатического формования

на морфологию и свойства

нетканых изделий

Для всех растворов полимеров были получены ультратонкие волокна с равномерной структурой поверхности без дефектов, с различным распределением по величине диаметра волокон (рис. 3а). Диаметр волокон, полученных из раствора ПЗГБ/ПЛА, изменялся незначительно в пределах 6-7 мкм, при среднем значении 6,5 мкм. При использовании раствора ПЗГБ/ПГ в распределении диаметра волокон отмечены два экстремума при значениях $\mathrm{d}=1,5$ и $\mathrm{d}=4,5$ мкм, что может указывать на плохие растворимость и смешиваемость ПГ с другими полимерами. У нетканых изделий состава ПЗГБ/ПЛГ максимальное зна- чение диаметра волокон составило 9,0 мкм, средний диаметр - 8,2 мкм.

Следующим этапом эксперимента было изготовление нетканых изделий методом электростатического формования с использованием двух подающих капилляров на один собирающий коллектор. Цель - изготовление нетканого материала с двумя отдельными типами полимерных ультратонких волокон в одном слое.

В результате из всех пар полимерных растворов были получены нетканые изделия с различным пространственным распределением ультратонких волокон по слоям (рис. 3б). Образцы, сформированные из ПЗГБ и ПЛА, в одном слое содержали волокна различных диаметров (1,5 и 4,5 мкм). Нетканые изделия, сформированные из ПЗГБ и ПГ, имели чёткое пространственное разграничение диаметра волокон по разным слоям изделия. Величины среднего диаметра волокон составляли 1,0 и 5,5 мкм. Образец с составом ПЗГБ и ПЛГ имел похожую слоистую структуру мембраны, как нетканое изделие, полученное из ПЗГБ и ПГ. Средние диаметры волокон составляли 1,0 и 4,5 мкм.

Сопоставление полученных значений диаметров волокон с полученными выше данными для волокон нетканых изделий, образованными из ПЗГБ, ПЛГ, ПГ, позволяет предположить, что при формировании нетканого изделия при использовании двух подающих капилляров для этих полимеров происходит пространственное распределение по слоям волокон, имеющих различную химическую структуру.

Результаты сравнения физикомеханических характеристик нетканых изделий, сформированных из полимеров при использовании одного и двух подающих капилляров на один собирающий коллектор, приведены в табл. 
ПЗГБ/ПЛА

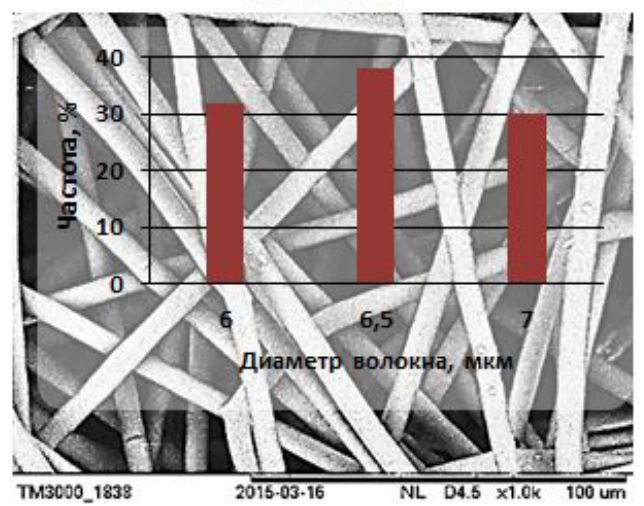

ПЗГБ/ІІГ

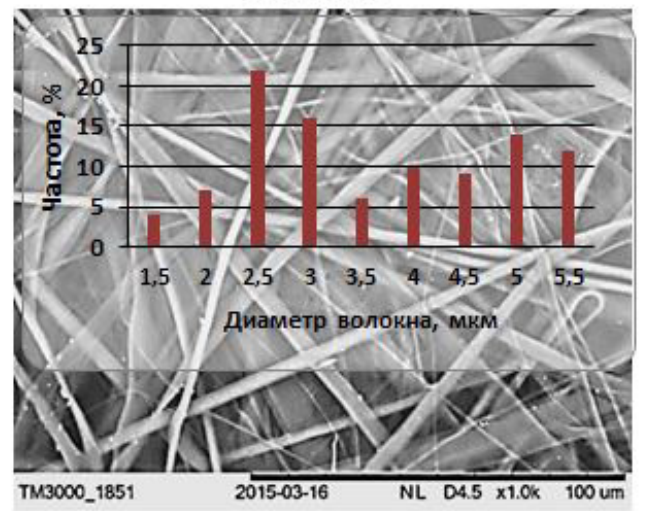

ПзГБ/ПЛГ

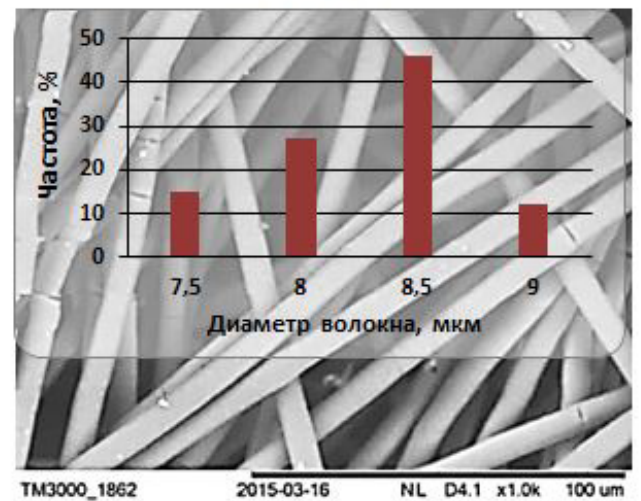

a
ПЗГБ и ПЛА

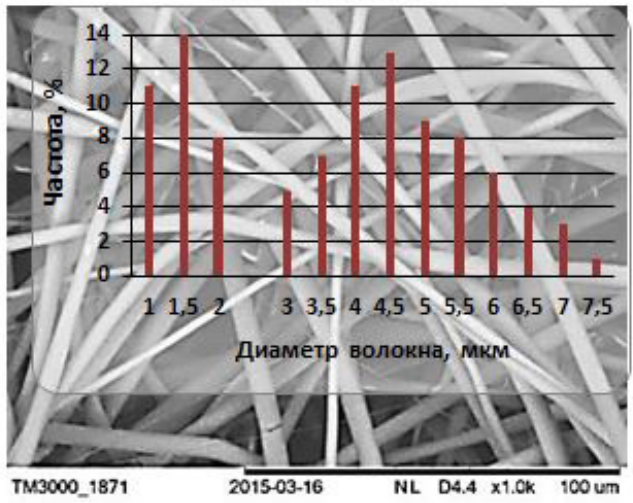

ПЗГБ и ПГГ

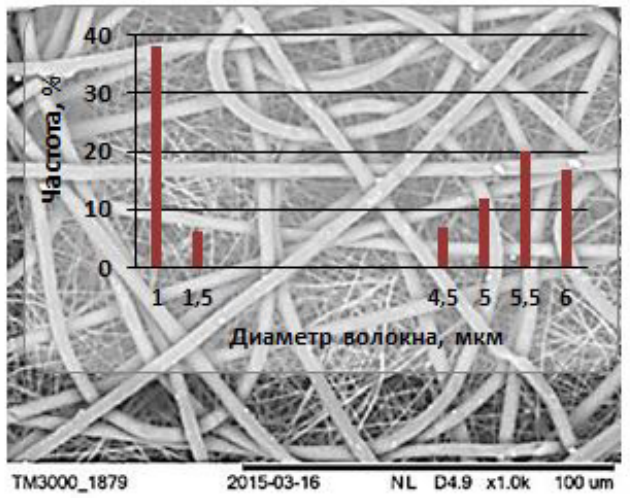

ПЗГБ и ПЛГ

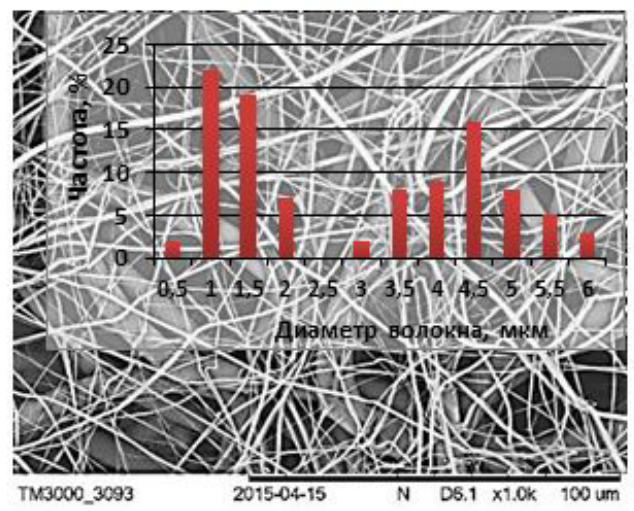

6

Рис. 3. РЭМ-изображения и распределение диаметра волокон нетканых изделий из поли-3гидроксибутирата, полилактида, полигликолида и сополимера поли(лактид-гликолида), полученных с использованием: a - одного подающего капилляра; б - двух подающих капилляров на один собирающий коллектор 
Таблица. Физико-механические характеристики (модуль Юнга (Е, МПа), напряжение при разрыве (б, МПа) и удлинение при разрыве $(\varepsilon, \%))$ нетканых изделий, полученных с использованием одного или двух подающих капилляров на один собирающий коллектор

\begin{tabular}{|c|c|c|c|c|c|}
\hline Номер п/п & Состав & $\begin{array}{c}\text { Количество } \\
\text { подающих } \\
\text { капилляров }\end{array}$ & Е, МПа & $\sigma$, МПа & $\varepsilon, \%$ \\
\hline 1 & ПЗГБ/ПЛА & 1 & $279 \pm 30$ & $2,6 \pm 0,2$ & $30 \pm 2$ \\
2 & ПЗГБ и ПЛА & 2 & $110 \pm 12$ & $1,7 \pm 0,1$ & $30 \pm 4$ \\
3 & ПЗГБ/ПГ & 1 & $197 \pm 18$ & $4,7 \pm 0,3$ & $18 \pm 3$ \\
4 & ПЗГБ и ПГ & 2 & $89 \pm 10$ & $1,3 \pm 0,1$ & $19 \pm 2$ \\
5 & ПЗГБ/ПЛГ & 1 & $220 \pm 25$ & $1,8 \pm 0,1$ & $11 \pm 4$ \\
6 & ПЗГБ и ПЛГ & 2 & $142 \pm 17$ & $1,5 \pm 0,1$ & $7 \pm 2$ \\
\hline
\end{tabular}

Эластичность образцов, определяемая по величине удлинения при разрыве $(\varepsilon, \%)$, определялась только составом растворов полимеров и не зависела от способа формирования нетканого изделия. Механическая прочность, характеризуемая величинами модуля Юнга (Е, МПа) и напряжения при разрыве $(\sigma$, МПа), при формировании нетканого изделия с использованием одного подающего капилляра на один собирающий коллектор была в два раза выше, чем у образцов, полученных с использованием двух подающих капилляров (из двух разных полимерных растворов одновременно).

\section{Характеристика поверхности}

нетканых изделий

Величина контактного краевого угла смачивания водой нетканых изделий определяет гидрофильность поверхности. С уменьшением угла увеличивается гидрофильность поверхности, с увеличением - гидрофобность.

На рис. 4 представлены результаты измерения контактных краевых углов смачивания водой нетканых изделий.

Для исходных ПЗГБ, ПЛА, ПГ и сополимера ПЛГ самые высокие значения краевого угла смачивания водой зафиксированы для нетканых изделий из чистого полилактида и поли(лактид-гликолида) $-116,7^{\circ} \pm 8,0^{\circ}$ и $119,6^{\circ} \pm 3,9^{\circ}$ соответственно. Образцы нетканых изделий, сформированных из ПЗГБ и ПГ, имели более низкие значения $-100,2^{\circ} \pm 11,8^{\circ}$ и $102,7^{\circ} \pm 3,8^{\circ}$ соответственно.

Для нетканых изделий, полученных с использованием одного подающего капилляра и смесей изучаемых полимеров, зафиксированы следующие значения контактных краевых углов смачивания водой: $113,9^{\circ} \pm 6,3^{\circ}$ для раствора полимеров ПЗГБ/ПЛА; 81, $8^{\circ} \pm 6,7^{\circ}$ - для ПЗГБ/ПГ и $100,1^{\circ} \pm 4,8^{\circ}-$ для ПЗГБ/ПЛГ.

Таким образом, при формировании нетканого изделия с использованием одного подающего капилляра добавление полилактида в раствор с ПЗГБ повышает гидрофобность поверхности полученного материала, что может быть связано со свойствами чистого полилактида. В свою очередь, использование смеси ПЗГБ и ПГ позволяет получить материал с самыми высокими показателями гидрофильности поверхности (величина угла составила $81,8^{\circ} \pm 6,7^{\circ}$ ).

Образцы из ПЗГБ/ПЛГ имели среднее значение контактного краевого угла смачивания водой из всех полученных композитных мембран, сопоставимое с этим показателем для чистого ПЗГБ. 


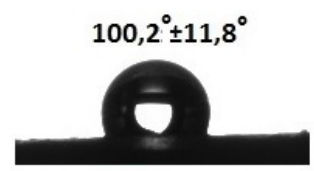

Пзгь

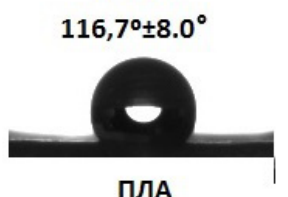

пЛА
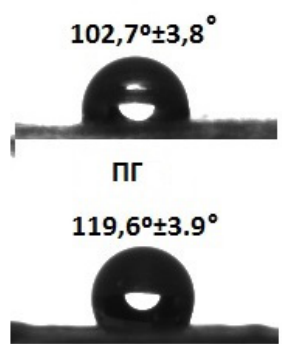

плг
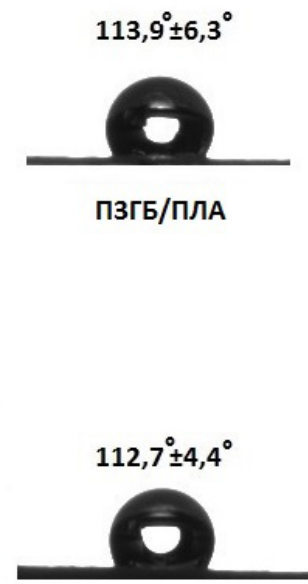

ПЗГБ и ПЛА

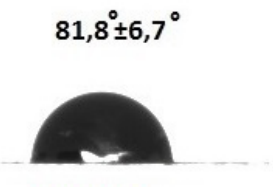

пзгь/пг

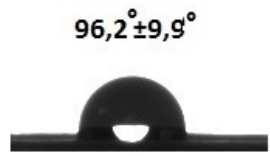

ПЗГБ и ПГ

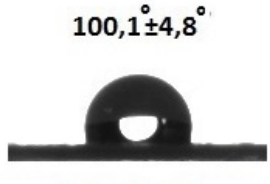

пзгь/плг

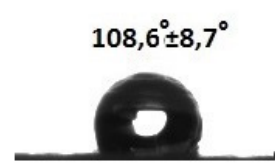

пзгБ и плг

Рис. 4. Снимки контактных краевых углов смачивания водой на нетканых изделиях из поли-3гидроксибутирата, полилактида, полигликолида и сополимера поли(лактид-гликолида) и изделий из сополимеров, полученных с использованием одного подающего капилляра (верхний ряд) и двух подающих капилляров (нижний ряд) на один собирающий коллектор

Величины контактного краевого угла смачивания водой для нетканых изделий, полученных с использованием двух подающих капилляров, составили $112,7^{\circ} \pm 4,4^{\circ}$ для ПЗГБ и ПЛА; $96,2^{\circ} \pm 9,9^{\circ}$ для ПЗГБ и ПГ; $108,6^{\circ} \pm 8,7^{\circ}$ для ПЗГБ и сополимера ПЛГ. Таким образом, включение волокон полилактида в структуру нетканого изделия способствует повышению величины контактного краевого угла смачивания водой относительно нетканых изделий из чистого ПЗГБ и росту гидрофобности поверхности нетканого изделия. Для нетканых изделий, полученных из растворов ПЗГБ и ПГ, отмечено снижение измеряемых углов смачивания и, как следствие, повышение величины гидрофильности.

\section{Заключение}

Методом электростатического формования с использованием одного подающего капилляра или двух подающих капилляров на один собирающий коллектор получены нетканые изделия из растворов полимеров поли3-гидроксибутирата, полилактида и полигликолида и сополимера поли(лактид-гликолида) и их смесей и исследованы их характеристики. Показано, что при использовании двух подающих капилляров происходит пространственное распределение по слоям нетканого изделия волокон, имеющих различную химическую структуру. Для физико-механических характеристик нетканых изделий обнаружена зависимость эластичности нетканого изделия от состава полимерного раствора, а механической прочности - от способа электростатического формования. Вне зависимости от способа электростатического формования состав используемых растворов полимеров позволяет влиять на гидрофильно-гидрофобные свойства нетканого изделия. 
Работа выполнена за счет средств государственного задания на проведение фундаментальных исследований РАН (проект № гос. регистрации 01201351505).

\section{Список литературы}

Волова Т.Г., Гончаров Д.Б., Суковатый А.Г., Шишацкая Е.И. (2013) Влияние параметров электростатического формования на характеристики наноматриксов из разрушаемых полиэфиров «Биопластотан». Пластические массы, 7: $52-56$ [Volova T.G., Goncharov D.B., Sukovaty A.G., Shishatskaya E.I. (2013) Effect of electrospinning parameters on the characteristics of nanomats of degradable polyesters «Bioplastotan». Plastics masses [Plasticheskie massy], 7: 5256 (in Russian)]

Гончаров Д.Б., Николаева Е.Д., Суковатый А.Г., Шабанов А.В., Шишацкая Е.И., Маркелова Н.М. (2012) Характеристики ультратонких волокон, полученных методом электростатического формования из поли-3-гидроксибутирата. Журнал Сибирского федерального университета. Биология, 5(4): 418-427 [Goncharov D.B., Nikolaeva E.D, Sukovaty A.G., Shabanov A.V., Shishatskaya E.I., Markelova N.M. (2012) Features of ultrafine fibers made by electrostatic formation from poly(3-hydroxybutyrate). Journal of Siberian Federal University. Biology [Zhurnal Sibirskogo federalnogo universiteta. Biologiya], 5(4): 418-427]

Николаева Е.Д., Гончаров Д.Б., Шишацкая Е.И. (2011) Влияние обработки Н2О2-плазмой на свойства клеточных носителей из резорбируемых полиэфиров «Биопластотан». Клеточная трансплантология и тканевая инженерия, 6(2): 65-70 [Nikolaeva E.D, Goncharov D.B., Shishatskaya E.I. (2011) Effects of H2O2-plasma processing on properties of cellular scaffolds made of «Bioplastotan» resorbing polyesters. Cell transplantation and tissue engineering [Kletochnaya transplantologiya i tkanevaya inzheneriya], 6(2): 65-70]

Buschle-Diller G., Hawkins A., Cooper J. (2006) Electrospun nanofibers from biopolymers and their biomedical applications. Modified Fibers with Medical and Specialty Applications, 10: 67-80

Hosseini Ravandi S.A., Gandhimathi C., Valizadeh M., Ramakrishna S. (2014) Application of electrospun natural biopolymer nanofibers. Current Nanoscience, 9: 423-433

Huang Z.-M., Zhang Y.-Z., Kotaki M., Ramakrishna S. (2003) A review on polymer nanofibers by electrospinning and their applications in nanocomposites. Composites Science and Technology, 63: 2223-2253

Kancheva M., Toncheva A., Manolova N., Rashkov I. (2015) Enhancing the mechanical properties of electrospun polyester mats by heat treatment. Polymer Letters, 9: 49-65

Katarzyna M.S., Gouma P. (2006) Electrospun composite nanofibers for functional applications. Journal of Nanoparticle Research, 8: 769-781

Khalil A.K., Fouad H., Elsarnagawy T., Almajhdi F.N. (2013) Preparation and characterization of electrospun PLGA/silver composite nanofibers for biomedical applications. Int. J. Electrochem. Sci., 8: $3483-3493$

Kriegel C., Arecchi A., Kit K., McClements D.J., Weiss J. (2008) Fabrication, functionalization, and application of electrospun biopolymer nanofibers. Critical Review. Food Science Nutrition, 48: $775-797$

Pham Q.P., Sharma U., Mikos A.G. (2006) Electrospinning of polymeric nanofibers for tissue engineering applications: a review. Tissue engineering, 12: 1197-1211

$$
-221-
$$


Philip S., Keshavarz T., Roy I. (2007) Polyhydroxyalkanoates: biodegradable polymers with a range of applications. J. Chem. Technol. Biotechnol., 82: 233-247

Sahay R., Kumar P.S., Sridhar R., Sundaramurthy J., Venugopal J., Mhaisalkarc S.G., Ramakrishna S. (2012) Electrospun composite nanofibers and their multifaceted applications. Journal Material Chemistry, 22: 12953-12971

Schiffman J.D., Schauer C.L. (2008) A review: electrospinning of biopolymer nanofibers and their applications. Polymer Reviews, 48: 317-352

Teo W.E., Ramakrishna S. (2006) A review on electrospinning design and nanofibers assemblies. Nanotechnology, 17: 89-106

Volova T., Goncharov D., Sukovatyi A., Shabanov A., Nikolaeva E., Shishatskaya E. (2014) Electrospinning of polyhydroxyalkanoate fibrous scaffolds: effects on electrospinning parameters on structure and properties. Journal of Biomaterials Science, Polymer Edition, 25: 370-393

Zhang C.L., Yu S.H. (2014) Nanoparticles meet electrospinning: recent advances and future prospects. Chemistry Society Review, 43: 4423-4448 